\title{
Victimization of the Homeless: Perceptions, Policies, and Implications for Social Work Practice
}

\author{
Marion M. Turner \\ Western Kentucky University \\ Simon P. Funge \\ Western Kentucky University \\ Wesley J. Gabbard \\ Western Kentucky University
}

\begin{abstract}
Homeless individuals are particularly vulnerable to victimization, sometimes resulting in fatalities. Theories of victimization prove useful to understanding the risks inherent in being homeless as well as the public's perception of the homeless population. Problematically, public policy that criminalizes this population may exacerbate the victimization of this group. Municipalities have turned to law enforcement and the criminal justice system to respond to people living in public spaces. Programs that ensure adequate income, affordable housing, and supportive services to prevent homelessness and address the needs of those who are homeless are essential. In addition, increased law enforcement training and the implementation of legislation to include homeless persons as a protected class in hate crime statutes is needed. In effect, these interventions focus on reducing the risks associated with being homelessness-in turn reducing the risk of their further victimization. Social workers are both uniquely positioned and ethically obligated to support these efforts and contribute to the social inclusion of people who are homeless or at risk of becoming homeless.
\end{abstract}

Keywords: homelessness, violence, social work practice, criminology, social policy

\section{Introduction}

On August 11, 2006, a homeless woman, Tara Cole, was pushed into the Cumberland River in Nashville, Tennessee (Strobel, 2006). She was sleeping on the dock when two men pushed her into the river, where she drowned. The men pled guilty and when asked about the incident; they reported that they were drunk and pushed Ms. Cole into the river as a prank ("2 Plead Guilty," 2007). On July 3, 2013, in Doylestown, Pennsylvania, George Mohr, a 71-year-old veteran, was found bleeding and unconscious after being brutally assaulted (National Coalition for the Homeless [NCH], 2014). Beaten and stabbed in the head, chest, arms, hands, and back, Mr. Mohr was taken to a hospital where he remained in critical condition until he died several days later (NCH, 2014). These seemingly random, senseless, and violent acts shocked the country; however, crimes like these as well as nonfatal attacks and other forms of victimization have become far too common for those who are experiencing homelessness.

The homeless are more exposed, have often been traumatized, and may experience ongoing health and mental health problems but may have weak connections to people, places, and institutions that could otherwise provide support and protection (Lee \& Schreck, 2005; Muñoz, Crespo, \& PérezSantos, 2005). For these reasons, they are disproportionately victimized by violence and crime. 
According to the NCH (2014), 1,437 acts of violence against the homeless were reported in the United States in the 15 years preceding its report, and approximately one in six (16.5\%) attacks resulted in fatalities (NCH, 2014). Troublingly, between 1999 and 2013, the total number of homeless individuals killed was nearly triple the number of individuals murdered from all other protected classes combined during this period. These included individuals who were killed based on the perpetrators' biases against members of their race, color, nationality, ethnicity, religion, ability status, or sexual orientation (NCH, 2014). These groups are those defined in federal law as "protected classes" (Stoops, 2005). Individuals who experience homelessness are frequent victims of nonfatal crimes as well, including burglary, petty larceny, motor vehicle theft, robbery, and physical assaults, and have been the target of offensive speech, threats, and insults (Merrill, 2012; Wachholz, 2005). However, reports of victimization may be underreported. For instance, Novac, Hermer, Paradis, and Kellen (2009) found that only one in five homeless youth and adults reported being a victim of a crime including physical assaults, whereas only three in 10 of homeless women were found to report being assaulted to authorities (Jasinski, Wesely, Wright, \& Mustaine, 2010). This underreporting may be a function of the harassment and brutality homeless individuals have experienced (or fear experiencing) in their interactions with the police who may be overzealous in their enforcement of quality-of-life issues (sometimes by municipal mandate) or undertrained in their understanding of mental illness and other factors contributing to-and as a consequence of homelessness (Georgiades, 2015; Simpson, 2015).

In spite of these challenges-or possibly as a consequence of these challenges-the homeless have been viewed as nonproductive members of society undeserving of more substantive efforts to address their rights and needs (Belcher \& DeForge, 2012). In contrast, with greater exposure to the homeless the public have been more likely to acknowledge the structural causes of homelessness (versus the personal failures of individuals experiencing homelessness; Agans et al., 2011; Lee, Farrell, \& Link, 2004). Given these competing views, the public may simultaneously attribute homelessness to individual factors while also advocating for more coercive measures such as the forcible removal of homeless individuals from public spaces (Knecht \& Martinez, 2009; Tompsett, Toro, Guzicki, Manrique, \& Zatakia, 2006).

As human service providers who often work with this population, professional social workers can and should advocate for a more systemic understanding of homelessness that supports policies to address and alleviate the victimization of this group. This effort can complement the American Academy of Social Work and Social Welfare's (Henwood et al., 2015) grand challenge to social work practitioners, researchers, policymakers, and allied professions to play an instrumental role in ending homelessness. However, as they work toward this goal, advocates may face limited support and/or opposition as a result of the public's negative perceptions about this population.

The goal of this article is to describe several theories of victimization as a means to frame these perceptions and argue that more individualistic explanations of the causes and consequences of homelessness (i.e., victim blaming) inform more punitive public policy responses that ultimately reinforce the potential for this group to continue to be victimized. In contrast, it is argued that public perceptions that acknowledge the causes and consequences of homelessness as largely outside of the individual's control can provide the justification for a more effective response to addressing the needs of this group - thus diminishing the possibility of their further victimization. And because social workers are called to challenge social injustice (National Association of Social Workers [NASW], 2015b), specific programmatic and policy recommendations are provided. 


\section{Review of the Literature}

Explanations regarding the causes of victimization not only have value in terms of understanding the variety of reasons why and how people who are homeless are particularly vulnerable, but also how the public may perceive their victimization, and in turn, their views regarding appropriate policy responses to homelessness. These theories range from those that conceptualize victimization as a response to an individual's behavior to those that focus on structural or systemic causes at the community level.

\section{Theories of Victimization}

\section{Victim Precipitation Theory}

This theory frames victimization as precipitated by or provoked by the victim's own behaviors (i.e., victims may either intentionally or inadvertently influence a perpetrator to victimize them; Wilcox, 2010). Active precipitation implies that the victim deliberately tries to provoke an attack. In contrast, passive precipitation implies the victim unconsciously displays behaviors or characteristics that may prompt the victimization. For the homeless, there may be circumstances where they actively engage in verbal or physical altercations with others who, in turn, victimize them. In fact, an association between substance use, violence, and victimization amongst homeless youth has been found and homeless youth may use violence to resolve disputes only later to be similarly victimized by their peers (Baron, Forde, \& Kennedy, 2007; Heerde \& Hemphill, 2014). The implication here is that some victimization may be actively precipitated by the homeless themselves. However, it is important to note that based upon crime data reported by NCH (2014), no perpetrators of the violent crimes against the homeless they cite were acting in self-defense. Implied is the likelihood that the victimization of the homeless described in the report was passively precipitated by the victim's unconscious behaviors or characteristics rather than as a result of their active engagement with their victimizers.

\section{Lifestyle Theory}

Individuals may be victimized as a result of their lifestyle, which may expose them to situations where victimization may be more likely (Wilcox, 2010). This may include their length of time in public spaces (particularly at night), isolation from support networks, or heightened exposure to potential offenders. Lee and Schreck (2009) hypothesized that homeless individuals' vulnerability to victimization is increased by their lifestyle, which is often a result of desperate choices. They may engage in activities born out of a need to survive such as panhandling, sleeping outside, prostitution, food scavenging, drug and alcohol distribution (and use), which may in turn contribute to the likelihood of their victimization.

\section{Deviant Place Theory}

Similar to lifestyle theory, deviant place theory posits that exposure to dangerous places makes an individual more likely to become the victim of a crime (Gaetz, 2009). Unlike victim precipitation theory, victims do not actively or passively instigate crimes against them; rather, they are victimized because they are in an environment that increases their exposure to risks. Different from lifestyle theory, which suggests that victims choose the lifestyle that contributes to their vulnerability, victims may inadvertently find themselves in an unsafe environment with little to no opportunity to move to a different place to protect themselves. This is likely to be the case for homeless persons who frequently find themselves in unsafe places where they are exposed (Gaetz, 2009). This can include living in unsafe, abandoned buildings, areas of cities where there are higher crime rates, and less fortified structures such as tents and cars. 


\section{Social Exclusion Theory}

Restricted access to the social, economic, political, and cultural systems of a community may inhibit individuals' ability to integrate into their community (Gaetz, 2004). As a result, they may be become disconnected from the very resources that would otherwise protect them from victimization. In the case of the homeless, having limited access to adequate housing, employment opportunities, social supports and a healthy lifestyle renders them more vulnerable. Social exclusion could be a factor long before an individual becomes homeless, but may be intensified when they are no longer housed. Due to their compromised safety, health, and opportunity, it is difficult for them to escape social exclusion.

Whether precipitated by the victim, their location, their lifestyle, or as a consequence of social exclusion, people who are homeless are disproportionately victimized. Further, although coverage of homelessness has steadily increased over time, both newspapers and the professional literature have increasingly focused on individual rather than structural factors associated with the causes and effects of homelessness (Buck, Toro, \& Ramos, 2004). As a result, the public holds disparate views regarding the nature, causes, and consequences of homelessness (Agans et al., 2011; Buck et al., 2004).

\section{Blaming the Victim}

Particularly in the United States, where dominant cultural values include independence, personal responsibility, and the concomitant belief that personal circumstances are a function of the choices people make, Savani, Stephens, and Markus (2011) found that this orientation tends to reduce empathy for those in need, increase the likelihood of blaming the victim for negative outcomes an individual may experience, and may diminish support for public policies that may seek to address the needs of marginalized individuals. Essentially, the process of victim blaming stems from the individual's belief that society is fundamentally just and that the negative outcomes experienced by another as a product of the victim's choices rather than as a result of systemic problems in the social environment. As a result, the individual may be more likely to dismiss or minimize the relevance and impact of the social context as it may have contributed to another's victimization. Consequently, the individual is less likely to support changes to the social context that may promote the public good.

Victim precipitation and lifestyle theories largely undergird public views of homelessness that effectively blame the victim. From these explanations, the individual would be less likely to be homeless and victimized should they choose different behaviors or a different lifestyle. These explanations reflect a more individualistic view of the causes and consequences of homelessness which may lead those who hold them to support (or be less likely to oppose) policies that effectively police the behaviors of people who are homeless. In contrast, deviant place and social exclusion theories provide explanations that identify factors largely outside of the control of the individual. A public that holds these views is more likely to recognize the role of structure in the cause and consequences of homelessness, and may be more likely to support (or less likely to oppose) changes

that are systemic in nature. However, as implied above, the public may simultaneously express both individualistic and structural views in their explanations for the causes and consequences of homelessness. Nevertheless, more individualistic views have proven more influential in public policy responses to homelessness.

\section{Criminalizing the Homeless}

Cities across the country have turned to law enforcement and the criminal justice system to respond to quality of life issues such as people living in public spaces. Municipal codes against sleeping, 
standing, and eating in public have more than doubled since 1990, and antibegging, antisoliciting, antipeddling, vagrancy, loitering, and curfew laws effectively criminalize homelessness (Fisher, Miller, Walter, \& Selbin, 2015; NCH \& National Law Center on Homelessness and Poverty [NLCHP], 2006; NLCHP, 2016; Stuart, 2014; Weisberg, 2005). Though they are more likely to be arrested for order maintenance and property offenses (i.e., misdemeanors) than for felonies, homeless arrestees have been incarcerated for low-level, nonviolent crimes (Fitzpatrick \& Myrstol, 2011).

Concerns about general public health, crime and safety, the economic impact of homelessness on business interests, and aesthetic and general quality-of-life concerns have largely driven these efforts (Foscarinis, Cunningham-Bowers, \& Brown, 1999). Tourism remains among the primary motivators as local shop owners, chambers of commerce, tourism officials, and other business advocates have been frustrated by the presence of homeless individuals in their commercial districts perceiving their presence as a threat to their business interests (Culhane, 2010). However, when these city ordinances are not coupled with a sufficient number of shelter beds and services, they effectively increase costs for the homeless and costs to public safety, are a misallocation of police resources, and ultimately fail to achieve the goal of removing the homeless from the streets (Saelinger, 2006).

In reality, these laws effectively control the poor living on the streets and are a way for municipalities to avoid confronting the root of the problem (Gerry, 2007; Mitchell, 2012). Thus, they reinforce negative perceptions about the homeless and lead the public's to support more punitive policies. As a consequence, the homeless population are further excluded and forced into increasingly deviant places where they are more susceptible to being victimized.

\section{Protecting and Empowering the Homeless}

More productive policy responses better address the structural issues that contribute to homelessness. They also provide a countervailing force against the negative public perceptions that are at the root of and emerge from more punitive policies and can go some way to reducing the likelihood of further victimization either by addressing the vulnerabilities associated with being homeless or ending homelessness altogether.

\section{Programs and Services}

The National Alliance to End Homelessness (NAEH; 2016) has highlighted a range of program and services to address the needs of those who may be temporarily homeless to those who are chronically homeless. Essentially, the group advocates that communities pursue public policies that ensure adequate income, affordable housing, and supportive services to prevent homelessness and address the needs of those who are homeless. For those who are at risk of homelessness, rapid rehousing programs provide temporary financial assistance and case management services to support individuals and families who are at risk of losing their housing or are temporarily without housing to return to permanent, stable housing as quickly as possible. Housing-first programs focus on moving homeless individuals and families into safe housing in an expedient manner and then blanketing them with short-term and long-term critical services as needed (NAEH, 2016; Padgett, Henwood, \& Tsemberis, 2015). These services may be intensive-particularly for those returning to the community after military service, hospitalization for physical or mental health needs, incarceration, or substance abuse treatment programs (NAEH, 2016). The integration of harm reduction supports and services (e.g., needle exchanges) with housing-first programs is also recommended so that an individual who is homeless and using drugs or alcohol still has access to supportive services (Pauly, Reist, Belle-Isle, \& Schactman, 2013). For homeless youth, family reunification may be a priority. 
But in other cases, long-term housing and supportive services including those former foster youth require to successfully transition into adulthood (e.g., life skills training, education and job training, and needs-based case management) may be needed.

In another critical area, although there have been cases in which excessive force and brutality have been used by officers against homeless individuals (NCH, 2012), law enforcement agencies in some municipalities can collaborate with social service providers and proactively train their officers to more effectively work with the homeless (U.S. Interagency Council on Homelessness, 2012). This process also reinforces to police the civil liberties of homeless individuals and families, as well as the fact that many have made (and will make) meaningful contributions to society given the right support systems.

In effect, programs and services should target a range of systems that foster and support the wellbeing of individuals who are experiencing or at risk of homelessness. These should be multisystemic, affecting every level of a homeless person's individual needs, care, family, employment, food, shelter, and overall wellbeing as a functioning member of their community. The desired outcome is to build the capacity of a community to support its residents such that the factors that may otherwise cause homelessness are reduced or eliminated and protective factors are enhanced (Banyard, 1995; Kilmer, Cook, Crusto, Strater, \& Haber, 2012; Novac, Serge, Eberle, \& Brown, 2002).

With each of these programs and services, the fundamental goal is to promote safety and/or contribute to the social inclusion of people who are homeless (or at risk of homelessness). In effect, these interventions focus on reducing the risks associated with being homelessness-in turn, reducing the risk of their further victimization.

Hate crimes legislation. A policy intervention not widely explored in the literature is the inclusion of people who are homeless as a protected class in hate crimes legislation. As previously noted, when compared with the number of homicides classified as hate crimes against individuals from other protected classes, the number of reported fatal attacks on the homeless has been disproportionately higher. In 2006, for example, three racially motivated attacks against individuals were fatal, whereas attacks against 20 homeless individuals resulted in deaths. And in 2012, 10 people in the United States were murdered based on their race, religion, or sexual orientation, whereas 18 homeless individuals were reported killed in the same year (NCH, 2014).

Originally defined in 1968 by the U.S. Congress, a hate crime is a crime in which a defendant intentionally selects a victim because of that individual's race, color, or national origin. It is an "illegal act motivated by the wish to harm groups or individuals whose affiliations, values, or actions are intolerable to the perpetrator" (Barker, 2003, p. 191). Over time, the definition of a hate crime has broadened to include additional protected identities such as ethnicity, religion, ability status, and sexual orientation (Stoops, 2005). Additionally, subsequent amendments to the original act have mandated that the U.S. Justice Department begin collecting data from law enforcement agencies about crimes motivated by prejudice (the 1990 Hate Crime Statistics Act) and increased penalties for perpetrators (the Violent Crime and Law Enforcement of 1994; Anti-Defamation League, 2012).

Although hate crimes legislation strives to protect those within a society who are deemed more vulnerable based on a particular trait (O'Keefe, 2010), the homeless are not currently recognized as a protected class despite the documented persistence of their victimization. However, several prominent homeless organizations have advocated that the homeless be included as a protected class. NCH (2014), NLCHP (2016), and the Anti-Defamation League (2012) have all endorsed the inclusion of homeless individuals in hate crimes legislation. 
However, because bias motivated crimes against the homeless are not currently recognized in federal hate crimes statutes, some states have moved forward to include the homeless as a protected class under state-level hate crimes statutes. In 2009, Maryland became the first state to add homeless persons to its list of protected categories under the state's existing hate crimes, opening the doors for other states to do the same (Associated Press, 2009).

In 2014, there were seven states and three cities that recognized violence against the homeless as a hate crime (Cain, 2014). Most recently, Representative Eddie Bernice Johnson (Democrat-Texas) introduced H.R. 1136, the Violence Against the Homeless Accountability Act of 2013. This act proposed to include homeless people as a protected class under the Hate Crimes Statistics Act (Cain, 2014). If implemented, it would have increased policymakers, advocates, and researchers' knowledge regarding the nature and extent of victimization, and plausibly serve to reduce victimization of the homeless; however, H.R.1136 was not enacted in the 113th Congress. No subsequent bill had been introduced at the time of this writing.

\section{Implications for Social Work Practice}

Social workers seek to promote social justice for vulnerable populations (NASW, 2015a). As professionals who provide services to people who are homeless, they are therefore ethically obligated to support changes that accomplish this. They are also uniquely motivated, qualified, and positioned to challenge negative perceptions about people who are homeless-particularly those who work directly with homeless populations (Weng \& Clark, 2018). This can be accomplished in part by advocating for best practices and policies that alleviate and address the victimization of people who are homeless (i.e., decriminalizing and protecting the homeless; Aykanian \& Lee, 2016). This includes educating the public about the extent to which the homeless population is victimized and disrupting views that attribute the causes of victimization to individual behaviors and focus instead on the consequences of social exclusion. In this way, social workers can be instrumental in shifting public perceptions away from those that effectively blame the victim for the causes and consequences of their homelessness which may then bolster support for more constructive approaches to reducing their victimization (Aykanian \& Lee, 2016). It also promotes the perception of the homeless as individuals with feelings, stories, and aspirations, rather than a crude stereotype in 21st-century society.

Moreover, NASW (2015) has advocated for broader access to affordable housing and a living wage, more targeted and coordinated services aimed at prevention and intervention, and political action on behalf of the homeless population. Existing organizations like NCH, NAEH, NLCHP, and Homeless Advocates Group advocate for, educate, and broker services for people who are homeless and need additional resources and support to successfully exit shelters and the streets.

People who are homeless need safety and protection to allow them to pursue opportunities that address their needs, not oppressive measures that criminalize them for quality-of-life issues (NCH \& NLCHP, 2006; NCH 2012). Social workers should advocate against the criminalization of the homeless and be in favor of productive approaches to addressing homelessness (Aykanian \& Lee, 2016). These include housing and supportive services programs such as Rapid Re-Housing and Housing First and harm-reduction initiatives as well as collaborative efforts with municipal law enforcement to train officers to better understand and more effectively respond to the needs of this population. In addition, because few states recognize crimes against the homeless as a hate crime, social workers should support federal and state legislative efforts to include homeless persons as a protected class in hate crime statutes. This advocacy can be part of broader overall efforts to shift the public's perceptions in a manner that simultaneously acknowledges the social exclusion of this 
population while building support for interventions that provide them with greater protections from being victimized.

\section{Conclusion}

Homeless individuals like Tara Cole and George Mohr were the victims of senseless cruelty. Unfortunately, stories such as theirs are not uncommon in 21st-century America. Although most victimization is nonfatal, it has significantly hurts a group of individuals who are already precariously housed and consistently marginalized on a daily basis. Thus, it is critical that social workers understand the reasons behind and manner in which the homeless are victimized (Weng \& Clark, 2018). Being cognizant of these factors allows them to better design interventions that counter oppressive practices and promote the safety and self-determination of folks living on the streets and in shelters. Further, social workers must understand how public perceptions inform and are informed by this victimization and advocate for interventions that protect those like Ms. Cole and Mr. Mohr, who remain vulnerable on the streets. Finally, they can support housing-first programs that focus on moving homeless individuals and families into places of safety before blanketing them with effective supportive services (NAEH, 2016; Padgett et al., 2015). These are all ways to help social workers rise to the grand challenges of ending the victimization of the homeless as well as ending homelessness altogether.

\section{References}

2 plead guilty in drowning of woman thrown in river. (2007, October 22). Knox News. Retrieved September 25, 2014, from http://www.knoxnews.com/news/state/2-plead-guilty-drowningwoman-thrown-river

Agans, R. P., Liu, G., Jones, M., Verjan, C., Silverbush, M., \& Kalsbeek, W. D. (2011). Public attitudes toward the homeless. Paper presented at American Association for Public Opinion Research Annual Conference: Public Perception and Societal Conflict, May 12-15, 2011, Phoenix, AZ.

Anti-Defamation League. (2012). Hate crime laws. Retrieved from http://www.adl.org/assets/pdf/combating-hate/Hate-Crimes-Law.pdf

Associated Press. (2009, May 8). Maryland: Attacking homeless becomes a hate crime. The New York Times. Retrieved from http://nyti.ms/1jc2x7I

Aykanian, A., \& Lee, W. (2016). Social work's role in ending the criminalization of homelessness: Opportunities for action. Social Work, 61, 183-185.

Banyard, V. L. (1995). "Taking another route": Daily survival narratives from mothers who are homeless. American Journal of Community Psychology, 23, 871-891. doi:10.1007/BF02507019

Barker, R. (2003). The social work dictionary (5th ed.). Washington, DC: National Association of Social Workers Press.

Baron, S. W., Forde, D. R., \& Kennedy, L. W. (2007). Disputatiousness, aggressiveness, and victimization among street youths. Youth Violence and Juvenile Justice, 5, 411-425. doi:10.1177/1541204077299582

Belcher, J. R., \& DeForge, B. R. (2012). Social stigma and homelessness: The limits of social change. Journal of Human Behavior in the Social Environment, 22, 929-946. doi:10.1080/10911359.2012.707941 
Buck, P. O., Toro, P. A., \& Ramos, M. A. (2004). Media and professional interest in homelessness over 30 years (1974-2003). Analyses of Social Issues and Public Policy, 4, 151-171. doi:10.1111/j.1530-2415.2004.00039.x

Cain, R., (2014, June 25). Actress testifies for homeless victims. Street Sense. Retrieved from http://www.huffingtonpost.com/street-sense/getting-the-homeless-expe_b_1118811.html

Culhane, D. P. (2010). Tackling homelessness in Los Angeles' Skid Row. Criminology \& Public Policy, 9, 851-857. doi:10.1111/j.1745-9133.2010.00675.x

Fisher, M., Miller, N., Walter, L., \& Selbin, J. (2015). California's new vagrancy laws: The growing enactment and enforcement of anti-homeless laws in the Golden State. Retrieved from http://considerthehomeless.org/pdf/CA_New_Vagrancy_Laws.pdf

Fitzpatrick, K. M., \& Myrstol, B. (2011). The jailing of America's homeless: Evaluating the rabble management thesis. Crime \& Delinquency, 57, 271-297. doi:10.1177/0011128708322941

Foscarinis, M., Cunningham-Bowers, K., \& Brown, K. (1999). Out of sight-out of mind? The continuing trend toward the criminalization of homelessness. Georgetown Journal of Poverty Law \& Policy, 6, 145-164.

Gaetz, S. (2004). Safe streets for whom? Homeless youth, social exclusion, and criminal victimization. Canadian Journal of Criminology and Criminal Justice/La Revue Canadienne De Criminologie Et De Justice Pénale, 46, 423-456. doi:10.3138/cjccj.46.4.423

Gaetz, S. (2009). Whose safety counts? Street youth, social exclusion, and criminal victimization. In D. Hulchanski, P. Campsie, S. Chau, S. Hwang, \& E. Paradis (Eds.), Finding home: Policy options for addressing homelessness in Canada (pp. 282-305). Toronto, Canada: Cities Centre, University of Toronto.

Georgiades, S. (2015). The dire straits of homelessness: Dramatic echoes and creative propositions from the field. Journal of Human Behavior in the Social Environment, 25, 630-642. doi:10.1080/10911359.2015.1011254

Gerry, S. (2007). Jones v. City of Los Angeles: A moral response to one city's attempt to criminalize, rather than confront, its homelessness crisis. Harvard Civil Rights-Civil Liberties Law Review, 42, 239-251.

Hate Crime Statistics Act, Pub. L. No. 101-275, 104 Stat. 140 (1990).

Heerde, J. A., \& Hemphill, S. A. (2014). A systematic review of associations between perpetration of physically violent behaviors and property offenses, victimization and use of substances among homeless youth. Children and Youth Services Review, 44, 265-277. doi:10.1016/j.childyouth.2014.06.020

Henwood, B. F., Wenzel, S., Mangano, P. F., Hombs, M., Padgett, D. K., Byrne, T., ... Uretsky, M. C. (2015). The grand challenge of ending homelessness (Working Paper Number 9). Cleveland, $\mathrm{OH}$ : American Academy of Social Work and Social Welfare. Retrieved from http://aaswsw.org/wp-content/uploads/2015/04/Ending-Homelessness-GC-4-3-2015formatted-final.pdf

Jasinski, J., Wesely, J., Wright, J., \& Mustaine, E. (2010). Hard lives, mean streets violence in the lives of homeless women. Boston, MA: Northeastern University Press. doi:10.1086/659432

Kilmer, R. P., Cook, J. R., Crusto, C., Strater, K. P., \& Haber, M. G. (2012). Understanding the ecology and development of children and families experiencing homelessness: Implications for practice, supportive services, and policy. American Journal of Orthopsychiatry, 82, $389-401$. 
Knecht, T., \& Martinez, L. M. (2009). Humanizing the homeless: Does contact erode stereotypes? Social Science Research, 38, 521-534. doi:10.1016/j.ssresearch.2009.01.009

Lee, B. A., Farrell C. R., \& Link, B. G. (2004). Revisiting the contact hypothesis: The case of public exposure to homelessness. American Sociological Review, 69, 40-63. doi:10.1177/000312240406900104

Lee, B. A., \& Schreck, C. J. (2005). Danger on the streets: Marginality and victimization among homeless people. American Behavioral Scientist, 48, 1055-1081. doi:10.1177/0002764204274200

Merrill, T. D. (2012). Victimization: Homeless in the heartland (Doctoral dissertation). Retrieved from ProQuest Dissertations and Theses. (Accession Order No. 1532034)

Mitchell, J. B. (2012). Crimes of misery and theories of punishment. New Criminal Law Review, 15, 465-510. doi:10.1525/nclr.20I2.15.4.465

Muñoz, M., Crespo, M., \& Pérez-Santos, E. (2005). Homelessness effects on men's and women's health. International Journal of Mental Health, 34, 47-61.

National Alliance to End Homelessness (NAEH). (2016). Solutions. Retrieved from http://www.endhomelessness.org/pages/solutions

National Association of Social Workers (NASW). (2015a). Code of ethics. Washington, DC: Author. Retrieved from https://www.socialworkers.org/About/Ethics/Code-of-Ethics.aspx

National Association of Social Workers (NASW). (2015b). Social work speaks: National Association of Social Workers policy statements (10th ed., pp. 178-186). Washington, DC: Author.

National Coalition for the Homeless (NCH). (2012). Hate crimes and violence against people experiencing homelessness. Retrieved from http://www.nationalhomeless.org/factsheets/hatecrimes.html

National Coalition for the Homeless (NCH). (2014). Vulnerable to hate: A survey of hate crimes \& violence committed against homeless people in 2013. Retrieved from http://nationalhomeless.org/wp-content/uploads/2014/06/Hate-Crimes-2013-1.pdf

National Coalition for the Homeless $(\mathrm{NCH})$ \& the National Law Center on Homelessness and Poverty (NLCHP). (2006). A dream denied: The criminalization of homelessness in U.S. cities. Retrieved from http://www.nationalhomeless.org/publications/crimreport/report.pdf

National Law Center on Homelessness and Poverty (NLCHP). (2016). Housing not handcuffs: Ending the criminalization of homelessness in U.S. cities. Retrieved from https://www.nlchp.org/documents/Housing-Not-Handcuffs

Novac, S., Hermer, J., Paradis, E., \& Kellen, A. (2009). More sinned against than sinning? Homeless people as victims of crime and harassment. In D. Hulchanski, P. Campsie, S. Chau, S. Hwang, \& E. Paradis (Eds.), Finding home: Policy options for addressing homelessness in Canada (pp. 660-671). Toronto, Canada: Cities Centre, University of Toronto.

Novac, S., Serge, L., Eberle, M., \& Brown, J. (2002, March). On her own: Young women and homelessness in Canada. Ottawa, Canada: Status of Women Canada.

O'Keefe, K. (2010). Protecting the homeless under vulnerable victim sentencing guidelines: An alternative to inclusion in hate crime laws. William \& Mary Law Review, 52, 301-326.

Padgett, D., Henwood, B, \& Tsemberis, S. (2015). Housing first: Ending homelessness, transforming systems, and changing lives. New York, NY: Oxford. doi:10.1093/acprof:oso/97801999989805.001.0001 
Pauly, B., Reist, D., Belle-Isle, L., \& Schactman, C. (2013). Housing and harm reduction: What is the role of harm reduction in addressing homelessness? International Journal of Drug Policy, 24, 284-290. http://dx.doi.org/10.1016/j.drugpo.2013.03.008

Saelinger, D. (2006). Nowhere to go: The impacts of city ordinances criminalizing homelessness. Georgetown Journal on Poverty Law \& Policy, 13, 545-566.

Savani, K., Stephens, N. M., \& Markus, H. R. (2011). The unanticipated interpersonal and societal consequences of choice: Victim blaming and reduced support for the public good.

Psychological Science, 22, 795-802. doi:10.1177/0956797611407928

Simpson, J. (2015). Police and homeless outreach worker partnerships: Policing of homeless individuals with mental illness in Washington, DC. Human Organization, 74, 125-134. doi:10.17730/0018-7259-74.2.125

Stoops, M. (2005, September 1). Alarming rise in hate crimes against homeless people in United States. Retrieved from http://www.thestreetspirit.org/September2005/hatecrimes.htm

Strobel, C. (2006, August 31). As one woman learned, the homeless live amid street terrorism. Retrieved September 25, 2014, from http://www.roomintheinn.org/tara

Stuart, F. (2014). From "rabble management" to "recovery management": Policing homelessness in marginal urban space. Urban Studies, 51, 1909-1925. doi:10.1177/0042098013499798

Tompsett, C. J., Toro, P. A., Guzicki, M., Manrique, M., \& Zatakia, J. (2006). Homelessness in the United States: Assessing changes in prevalence and public opinion, 1993-2001. American Journal of Community Psychology, 37, 47-61. doi:10.1007/s10464-0059007-2

U.S. Interagency Council on Homelessness. (2012). Searching out solutions: Constructive alternatives to the criminalization of homelessness. Retrieved from https://www.usich.gov/tools-foraction/searching-out-solutions

Violence Against the Homeless Accountability Act, H.R. 1136, 113th Cong. (2013).

Violent Crime and Law Enforcement Act, Pub. L. No. 103-322, 108 Stat. 1796 (1994).

Wachholz, S. (2005). Hate crimes against the homeless: Warning-out New England style. Journal of Sociology and Social Welfare, 32, 141-163.

Weisberg, B. (2005). When punishing innocent conduct violates the eighth amendment: Applying the Robinson doctrine to homelessness and other contextual "crimes." Journal of Criminal Law \& Criminology, 96, 329-365.

Weng, S., \& Clark, P. (2018). Working with homeless populations to increase access to services: A social service providers' perspective through the lens of stereotyping and stigma. Journal of Progressive Human Services, 29, 81-101.

Wilcox, P. (2010) Victimization, theories of. In B. S. Fisher \& S. P. Lab (Eds.), Encyclopedia of victimology and crime prevention (pp. 978-986). Thousand Oaks, CA: Sage. doi:10.4135/9781412979993.n334 
The Journal of Social Work in the Global Community, sponsored by Walden University, is a scholarly peer-reviewed journal that promotes research in the practice of international social work with a focus on social change. JSWGC publishes high-level research, literature and book reviews, and thought pieces related to the field of social work practice and social change in our global community.

Walden University Publishing: http://www.publishing.waldenu.edu 